\title{
Impacts of a shallow shipwreck on a coral reef: A case study from St. Brandon's Atoll, Mauritius, Indian Ocean.
}

Veronica van der Schyff, Marinus du Preez, Karin Blom, Henrik Kylin, Nee Sun Choong Kwet Yive, J ulian Merven, J ovani Raffin and Hindrik Bouwman

The self-archived postprint version of this journal article is available at Linköping University Institutional Repository (DiVA):

http:/ / urn.kb.se/ resolve?urn=urn:nbn:se:liu:diva-163697

N.B.: When citing this work, cite the original publication.

van der Schyff, V., du Preez, M., Blom, K., Kylin, H., Choong Kwet Yive, N. S., Merven, J., Raffin, J ., Bouwman, H., (2020), Impacts of a shallow shipwreck on a coral reef: A case study from St. Brandon's Atoll, Mauritius, Indian Ocean., Marine Environmental Research, 156, 104916.

https:// doi.org/ 10.1016/j.marenvres.2020.104916

Original publication available at:

https:/ / doi.org/ 10.1016/j.marenvres.2020.104916

Copyright: Elsevier

http:// www.elsevier.com/

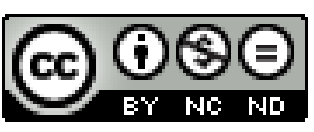




\title{
Impacts of a shallow shipwreck on a coral reef: A case study from St. Brandon's Atoll, Mauritius, Indian Ocean.
}

Veronica van der Schyffa ${ }^{*}$, Marinus du Preez ${ }^{a}$, Karin Blomª, Henrik Kylinn ${ }^{a, b}$, Nee Sun Choong Kwet Yivec ${ }^{c}$, Julian Merven ${ }^{d}$, Jovani Raffine, Hindrik Bouwman ${ }^{a}$

${ }^{a}$ Research Unit: Environmental Sciences and Management, North-West University, Potchefstroom, South Africa

${ }^{b}$ Department of Thematic Studies - Environmental Change, Linköping University, Linköping, Sweden 'Department of Chemistry, University of Mauritius, Mauritius

${ }^{d}$ Raphael Fishing Co. Ltd, Port Louis, Mauritius

eshoals Rodrigues, Marine Non-governmental Organisation, Rodrigues Island, Mauritius

*Corresponding author. E-mail address: veronica.vanderschyff@yahoo.com

\begin{abstract}
Shallow shipwrecks can have severe ecological and toxicological impacts on coral atolls. In 2012, a tuna longliner ran aground on the reef crest of St Brandon's Atoll, Mauritius, broke up into three pieces which was moved by currents and storms into the lagoon. In the months following the grounding, the coral around the wreck became dead and black. Down-current from the wreck, a dense bloom of filamentous algae (Ulva sp.) attached to coral occurred. To determine the ecological effects of the wreck on the system, the marine biota around the wreck, in the algal bloom, and fish reference zones were counted in 2014. Metal concentrations in reference and affected coral was determined using inductively coupled plasma mass spectrometry (ICP/MS). A pronounced difference was seen in the metal concentration pattern between coral from the wreck- and algal zones, and the coral reference zone. While the wreck zone contained the highest abundance of fish, the fish reference zone had the highest species diversity but with fewer fish. We also counted eleven Critically Endangered hawksbill sea turtles Eretmochelys imbricata and significantly more sea cucumbers in the algal zone than the reference zones. The effects of shipwrecks on coral reefs must be considered a threat over periods of years and should be studied further.
\end{abstract}

Keywords: algal bloom, black reefs, coral, ecotoxicology, fish, sea cucumbers

\section{Highlights}

- A tuna longliner shipwreck stranded on the edge of Saint Brandon's Atoll.

- Around the wreckage, corals were dead with a black colour.

- High metal concentrations in coral around the wreckage.

- Down-current of the wreck, a concentrated macroalgae bloom occurred. 


\section{Introduction}

Worldwide, the health of coral reefs is declining (Gardner et al., 2003; Porter \& Schleyer, 2017; Hughes et al., 2018; Baumann et al., 2019). Some of the causes are global such as rising sea temperatures (Carpenter et al., 2008) and ocean acidification (Millero et al., 2009). Others are localised threats, including damage caused by storms and recreational divers (Sheppard et al., 2009), or chemical threats such as oil spills and plastic debris (Allen et al., 2017).

Shipwrecks are often found on the shallow reef crests or back reefs of oceanic atolls, posing an intricate ecological conundrum as their presence impacts both positively and negatively on reefs. Shipwrecks provide structure for the formation of new coral reefs and shelter for fish and other sea-life, increasing the species richness and diversity of an area (Perkol-Finkel et al., 2006; Consoli et al., 2015). However, shipwrecks on coral reefs present a threat to reefs as they often cause physical damage to the reef and pollute the broader environment (Evans et al., 2016; Kelly et al., 2012; Yusuf, 2014). Physical damage is caused when strong wave action, storms, and strong currents break up the structure of ships, often pushing them across the reef crest into deeper waters, leaving scars on the lagoon floor. The initial damage caused by shipwrecks are often physical by crushing coral and other invertebrates, thereby possibly affecting topographic complexity (Precht et al., 2001). Outbreaks of coral diseases are also associated with shipwrecks (Raymundo et al., 2018). Chemical pollution occurs from the ship's fuel, cargo, and structure, influencing the ecology and toxicology of the surrounding reefs (Barrett, 2011). Shipping activities are also vectors for several invasive marine organisms. Macroalgae spores, including spores of several Ulva species have been recorded in ships ballast water (Flagella et al., 2007; Aguirre-Macedo et al., 2008). Species of the genus Ulva are opportunistic filamentous algae with a traditionally coastal distribution. It is now found in several sites outside the traditional known distribution (Zetuche-González et al., 2009; Yuping et al., 2015). Algal bloom growth resulting from macroalgae spores released from shipping activities can cause coral mortality by overgrowing coral colonies and smothering the organisms as they grow (Jompa \& McCook, 2003), outcompeting corals for resources, and reducing coral larvae settlement (McCook et al., 2001).

Numerous ships have been wrecked on St Brandon's Atoll (SBR) (Hancock, 2018). Although some of the wrecks have been recovered, such as the Team Vestas Wind racing yacht that stranded during the 2014 Volvo Ocean Challenge (Bouwman et al., 2016), many wrecks are not salvaged and remain on the atoll for years.

In October 2014, during an expedition to SBR to collect coral, fish, and plastic for pollutant analyses, we were made aware of the wreck of a 79.5 ton tuna longliner that ran 
aground on the south-eastern edge of SBR of the atoll reef crest in 2012 (Merven, J. pers. obs. 2014) (Figure 1). The vessel subsequently broke into three segments (the bow section that contained the cargo hold, the stern section with the engine room and fuel tanks, and the centre wheelhouse section) that were shifted by currents and storms across the lagoon to where they are now, approximately $6 \mathrm{~km}$ down current from the initial point of impact (Figure 1). The bow and stern are approximately $850 \mathrm{~m}$, with the wheelhouse approximately $670 \mathrm{~m}$ perpendicular from the stern (Figure 1). Our initial observations showed that this wreck and its subsequent breakup caused physical damage to the lagoon, and apparently contributed to a dense concentrated (approximately 40 hectare) algal bloom. An Ulva spp. bloom developed on coral heads down-current from the wreck, approximately $100 \mathrm{~m}$ from the wheelhouse (Figure 1). Such a bloom has not been observed before on SBR. (Merven, J. pers. obs. 2014).

The coral in the direct vicinity of the wreck fragments were noticeably blackened. Black reefs are formed due to an influx of iron from maritime debris- mostly shipwrecks or shipwreck associated debris- and is linked to the proliferation of benthic cyanobacterial communities and turf algae blooms (Schroeder et al., 2008; Kelly et al., 2012; Mangubhai \& Obura, 2019). Black reefs have been recorded in the Pacific Ocean, but this is the first instance where it is recorded in the Indian Ocean (Schroeder et al., 2008; Kelly et al., 2012; Mangubhai \& Obura, 2019). This posed a unique opportunity to study the ecological and toxicological effects of a shipwreck on a near-pristine island system in the western Indian Ocean.

There is no framework or comprehensive method of risk assessment for shipwrecks (Landquist et al., 2013). The aim of this research was to investigate the impact of the wreck using a two-fold approach with two objectives: examining the data from fish and sea cucumber transects, and measuring the metals in coral and algae collected from the wreck and reference zones.

We hypothesized that corals from the wreck - and algal zones would have a higher concentration of metals than corals from the coral reference zone. Furthermore, we predicted that the undisturbed reef reference (fish reference zone) would have a higher fish species richness, and that the wreck zone would have a higher fish abundance due to the structure afforded by the wreck pieces.

\section{Materials and methods}

\subsection{Study area and sampling zones}

St. Brandon's Atoll, forming part of the Cargados Carajos Shoals in the Mascarene Basin, is a $200 \mathrm{~km}^{2}$ coral reef island approximately $450 \mathrm{~km}$ north-east of Mauritius in the 
Indian Ocean (Evans et al., 2016; Quod, 1999; Figure 1). SBR is located upstream of where the South Equatorial Current splits at the coast of Madagascar. The current flows from the north of Australia and the Indonesian island chain to the western Indian Ocean (Schott \& McCreary Jr., 2001). There are no permanent residents on SBR, but there is a small permanent but rotating human presence of approximately 40 fishermen, meteorological station personnel, and National Coast Guards of Mauritius (Bouwman et al., 2016). The effect of the people residing on the atoll on the pollution of the area is considered minimal, except in the areas of settlements at Ile du Sud and lle Raphael. Most of the pollution on the atoll is from external sources, such as marine debris and pollutants transported by ocean currents (Bouwman et al., 2016). The wreck is located beyond where the Atoll's inhabitants normally venture.

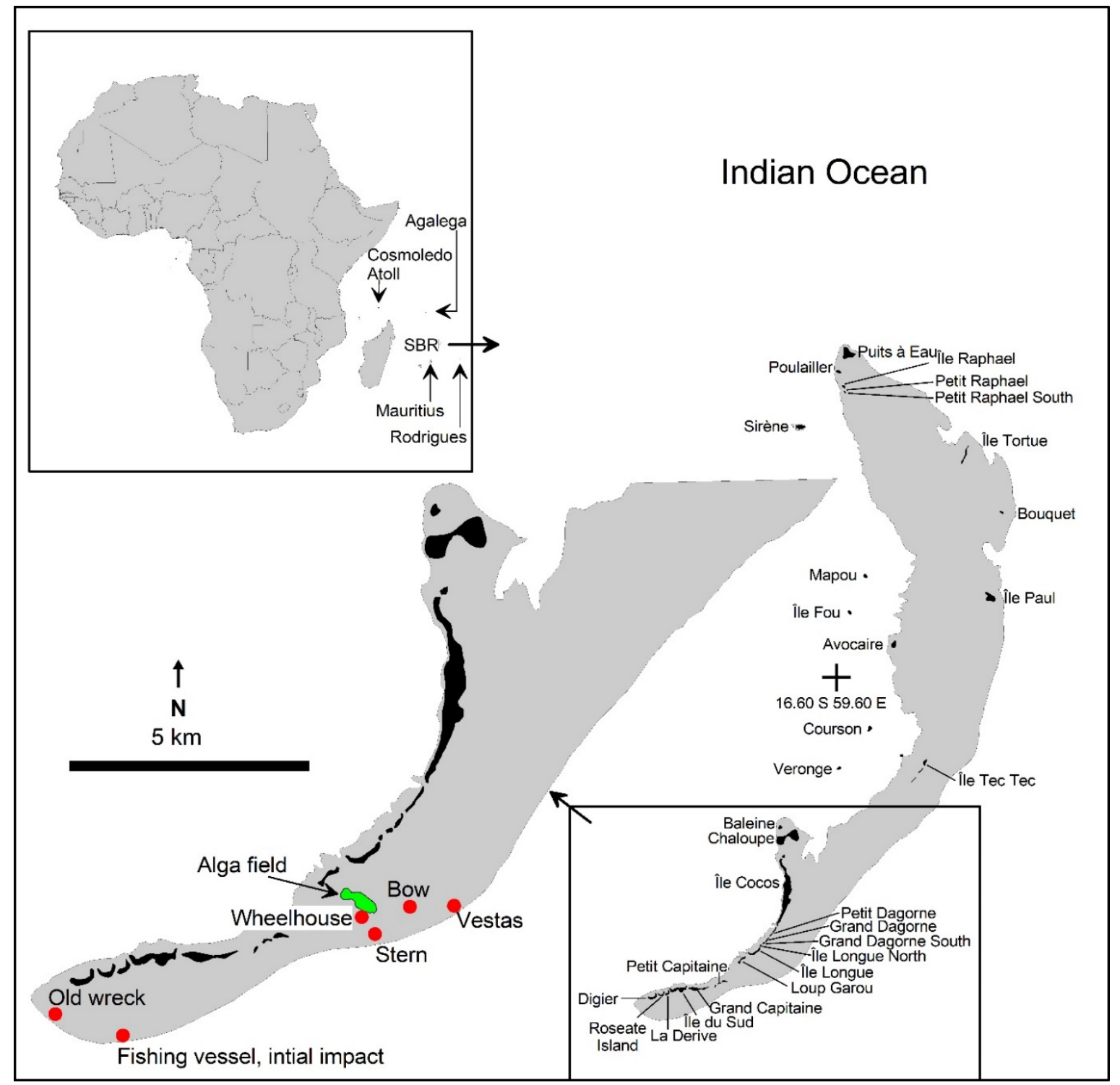

Figure 1. Location of the shipwreck sections and the algal bloom relative to St. Brandon's Atoll. 
Four zones were selected for surveys and sample collection. The water depth at all zones varied between one and three metres and strong currents from the south-west are dominant throughout the year. The respective zones are described as follow:

- The wreck zone is the area where the three wreck segments were located within eyeshot of each other, with the bow and stern separated by approximately one kilometre, and the wheelhouse approximately $500 \mathrm{~m}$ west from the stern (Figure 1). The coral in the immediate vicinity (ca. 20-50 m radius) of each section of wreck was dead and blackened (Figure 2) with many large fish. Each wreck section was individually surveyed for fish, sea cucumber, and coral, and sampled for blackened coral.

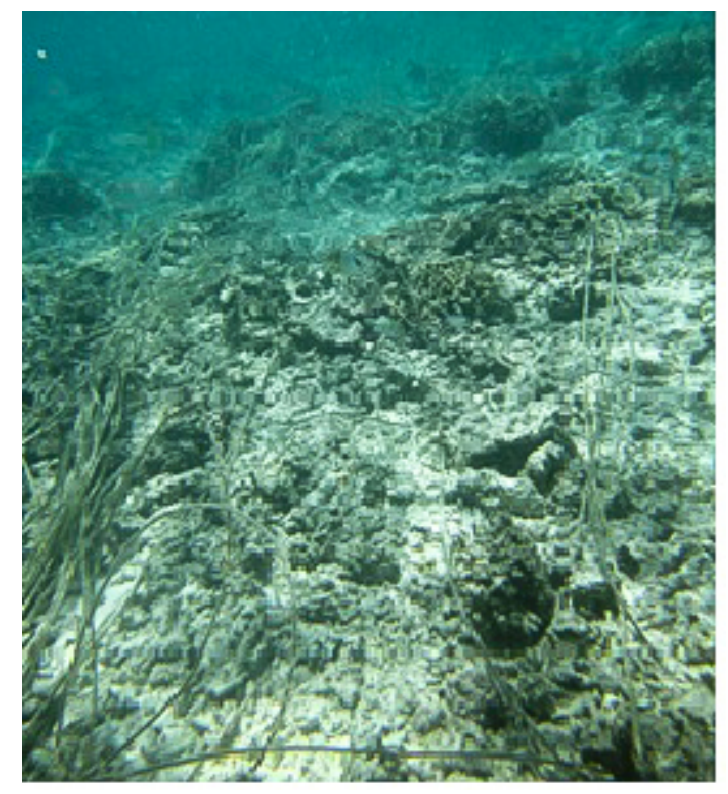

Figure 2. Blackened coral in the wreck zone

- The algal zone comprised 40 hectares of the lagoon where filamentous algae (Ulva spp.) grew down-current from the wreck (Figure 1). This algal bloom developed following the stranding of the fishing vessel in 2012 (Merven, J. pers. obs. related in 2014). We circumnavigated the algal zone with a small boat while recording the track with a GPS (Figure 1). The algae occurred in long strands, up to $10 \mathrm{~m}$, attached to coral heads. Much of the coral underneath the attached algae appeared dead or heavily stressed. This is evidenced by bleached sections of coral observed under the algal strands (see videos in Supplemental Materials). Many coral heads were broken, presumably due to the hydrodynamic drag of the strong currents imparted on the heads by the algae (Figure 3 ) as the broken coral heads were down-current from their attachments. Strands of algae 
and coral were collected and analysed for metals. Fish and sea cucumber abundance surveys were also conducted in this zone.

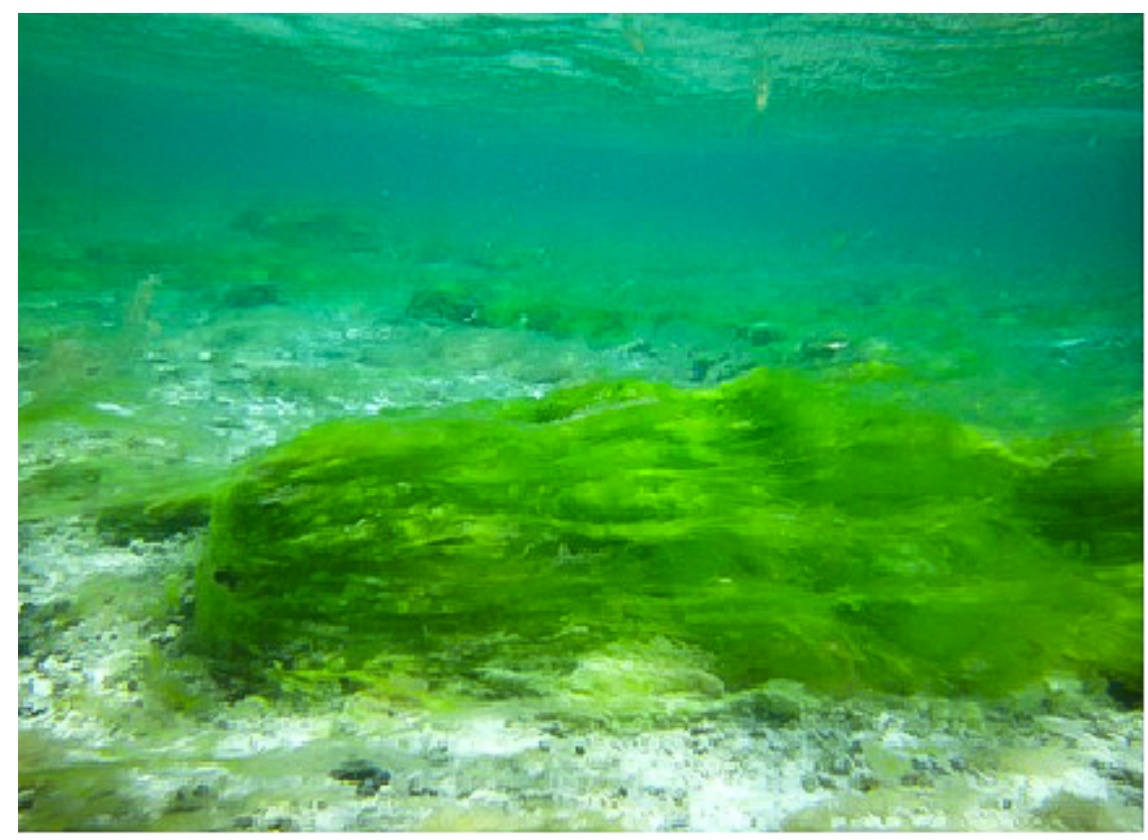

Figure 3. Macroalgal strands over a coral colony in the algal zone

- The fish reference zone is an area that was not affected by the current flowing from the wreck (Figure 1). No algal growth occurred here. The corals from this zone appeared healthy (Figure 4). Fish and sea cucumbers were surveyed here as a reference state.

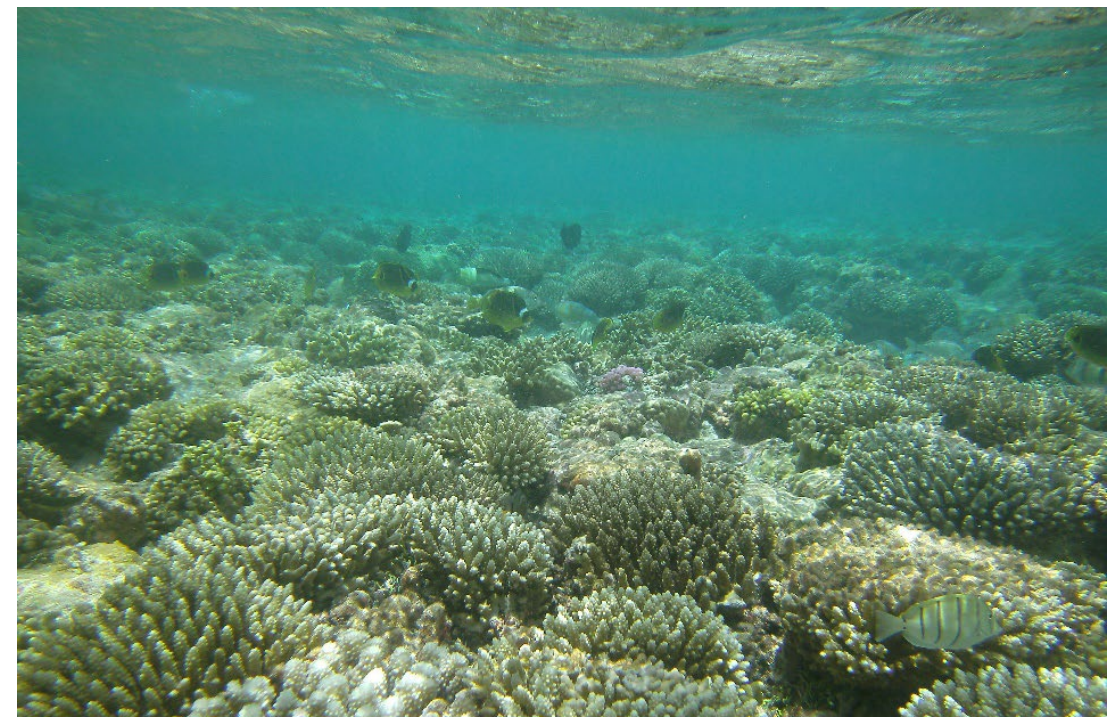

Figure 4. The fish reference zone reef, without macroalgae growth with seemingly healthy coral 
- The coral reference zone is located on the other side of the atoll, where the effect of the wreck and algae was deemed negligible. Coral genera were found in this area were similar to that in the algal zone and wreck zone. Samples of live colonies of Pocillopora spp. and Stylophora spp. were collected here. The reference corals were not collected from the fish reference site due to the proximity of the wreck- metals from the wreck may have contaminated corals down current.

\subsection{Fish and sea cucumber surveys}

Three, $50 \mathrm{~m}$ transects were surveyed in the algal zone, and four, $50 \mathrm{~m}$ transects in the fish reference zone. Fish and sea cucumber species and abundance were recorded while snorkelling, recording fish and sea cucumbers within $5 \mathrm{~m}$ either side of the transect line (50 $\mathrm{m}$ rope). The parallel transects were about $100 \mathrm{~m}$ apart, measured by GPS. An area of $5000 \mathrm{~m}^{2}$ was surveyed in the fish reference zone. Fish and sea cucumber abundance and species within a $50 \mathrm{~m}$ radius circle (an area of $7850 \mathrm{~m}^{2}$ ) around each wreck piece was recorded.

\subsection{Coral and algae sampling}

Pocillopora and Stylophora hard corals occurred in abundance in the wreck zone, algal zone, and coral reference zone. Fragments of live coral were collected from the algal zone and coral reference zone. In the wreck zone, where all coral close to the wreck were dead, fragments of dead colonies of both species were collected. The fragments of the two coral species per area were pooled, placed in plastic bags, and frozen at $-20^{\circ} \mathrm{C}$. Algae strands were collected from the centre of the algal zone and stored in high-density polyethylene bottles. Small paint chip fragments from the wreck were collected. The biological samples were shipped frozen to South Africa (Import permit No. P0075626) for chemical analysis in a frozen state.

\subsection{Laboratory analysis}

Coral fragments, algae strands, and paint chip samples were analysed for metal concentrations at EcoAnalytica Laboratory in Potchefstroom, South Africa, according to the United States Environmental Protection Agency (EPA 3051A) (EPA 1996). Two grams of finely ground, freeze-dried samples were heat- and acid digested using reagent grade $33 \%$ hydrochloric acid, 50\% hydrogen peroxide, and 65\% concentrated nitric acid (Associated Chemical Enterprises). The solution was heated and diluted to $50 \mathrm{ml}$ with deionised water $(18 \mathrm{M} \Omega \cdot \mathrm{cm})$ water, before analyses of 31 elements using inductively coupled plasma mass spectrometry (ICP-MS) (Agilent 7500c ICP-MS with standard quartz chamber and micromisttype nebulizer). A $1 \mu \mathrm{g} / \mathrm{l}$ solution of cerium, lithium, and thallium for low-oxide/low 
interference levels $(\leq 1.5 \%)$ was used to maintain sensitivity across the mass range.

External calibration was employed using certified ULTRASPEC mixed multi-element stock standard solutions (De Bruyn Spectroscopic Solutions) that contained all the elements of interest at different concentration levels. Full calibration sets and quality control check standards were run frequently. The detection limits for each element were calculated from the calibration curves with each calibration run. A standard reference material (SRM 1944 New York/New Jersey Waterway Sediment) was used for quality control. The concentrations of the certified elements were within $20 \%$ of certified values. Concentrations are expressed as milligram per kilogram on a dry mass basis $(\mathrm{mg} / \mathrm{kg} \mathrm{dm})$.

\subsection{Statistical analysis}

Graphpad Prism 8.1.0 (www.graphpad.com) was used for summary statistics and comparisons. Because the datasets were not normally distributed, we used the nonparametric, Kruskal-Wallis tests to test for variance between the metal concentrations of coral from the wreck zone, algal zone, and coral reference zone. The Dunn's multiple comparisons test was used to test the differences between pairs of samples. Significance was selected at $p<0.05$.

Nonmetric multidimensional scaling (NMS), using MjM Software PC-ORD 7.07 (www.pcord.com) was conducted to ordinate relative metal proportions in corals and algae. The data were relativised per element in order to obtain a proportional profile ('fingerprint') of metals in each sample. "Gower-ignore-0" was used as the distance measure. Five hundred runs of real data were used, from random starting conditions. A maximum of six axes were allowed. A second NMS was run with the same parameters to ordinate the relative fish diversity in the different zones. "Gower-ignore-0" was again used as the relative measure of distance.

\section{Results}

\subsection{Visual observations of the 'dead' zones of the wreck segments, and the algal field}

There were no live corals within a $10 \mathrm{~m}$ radius around each of the wreck segments, nor on the wreck segments themselves. The dead coral was blackened and broken. Black band diseases was disregarded as the cause of the coloration because the entirety of the affected colonies were black; the distinctive black band separating live tissue and dead white tissue (Barneah et al., 2007) was not seen in the affected area. Between the wreck segments and the algal field, live coral was present, but these appeared stressed with few fish present in the area. However, no quantitative surveys were conducted here. 
The algal field was located about $100 \mathrm{~m}$ away, down-current, from the closest wreck segment (Figure 1). This algal field was a striking phenomenon, as shown in Figure 3. Underwater, the damage to coral heads was quite apparent, probably caused by the hydrodynamic drag of the algae strands. The coral also appeared stressed, especially where the rhizoids of the algae were attached to the coral, and where the algae strands covered the coral (see Supplemental Materials).

\subsection{Metals in corals}

Mean concentrations of 16 environmental relevant metals are summarised in Table 1. The concentrations of other metals shown in Figure 5 are summarized in Supplementary Table 1. There were no significant differences between the coral samples from the three zones for $\mathrm{Al}, \mathrm{Ti}, \mathrm{V}, \mathrm{Mn}, \mathrm{Fe}, \mathrm{Co}, \mathrm{Ni}$, and $\mathrm{Hg}$. The wreck zone corals had significantly higher concentrations of $\mathrm{Cr}, \mathrm{Zn}$, and As than the coral reference zone. The algal zone corals had significantly higher concentrations of $\mathrm{Cu}, \mathrm{Cd}, \mathrm{Pb}$, and $\mathrm{U}$ compared with the coral reference zone. 
Table 1: Mean metal concentration ( $\mathrm{mg} / \mathrm{kg}$ dry mass $(\mathrm{dm})$ ) and standard deviations (in bracket) of paint chips $(\mathrm{n}=3)$ from the wrecks, Ulva spp. algae strands $(n=3)$ from the centre of the algal zone, pooled coral fragments from the algal zone $(n=3)$, wreck zone $(n=3)$, and coral reference zone $(n=6)$.

\begin{tabular}{|c|c|c|c|c|c|c|c|c|c|c|c|c|c|c|c|c|}
\hline & Al & $\mathrm{Ti}$ & $\mathbf{V}$ & $\mathrm{Cr}$ & $M n$ & $\mathrm{Fe}$ & Co & $\mathrm{Ni}$ & $\mathrm{Cu}$ & $\mathrm{Zn}$ & As & Cd & $\mathrm{Hg}$ & $\mathrm{Pb}$ & $\mathbf{U}$ & $\mathrm{Se}$ \\
\hline Paint chips & $\begin{array}{l}22000 \\
(2600)\end{array}$ & $\begin{array}{r}6200 \\
(8000)\end{array}$ & $\begin{array}{r}160 \\
(140)\end{array}$ & $\begin{array}{r}1500 \\
(1300)\end{array}$ & $\begin{array}{r}2400 \\
(3300)\end{array}$ & $\begin{array}{r}240000 \\
(330000)\end{array}$ & $\begin{array}{l}100 \\
(63)\end{array}$ & $\begin{array}{r}160 \\
(180)\end{array}$ & $\begin{array}{r}102000 \\
(140000)\end{array}$ & $\begin{array}{r}13000 \\
(17000)\end{array}$ & $\begin{array}{r}14 \\
(19)\end{array}$ & $\begin{array}{r}0.095 \\
(0.071)\end{array}$ & $\begin{array}{r}0.082 \\
(0.079)\end{array}$ & $\begin{array}{l}1000 \\
(760)\end{array}$ & $\begin{array}{r}7.1 \\
(4.7)\end{array}$ & $\begin{array}{r}0.052 \\
(0.014)\end{array}$ \\
\hline $\begin{array}{l}\text { Algae strands } \\
\text { Ulva spp. }\end{array}$ & $\begin{array}{l}9.5 \\
(1)\end{array}$ & $\begin{array}{r}2.2 \\
(0.45)\end{array}$ & $\begin{array}{r}1.5 \\
(0.36)\end{array}$ & $\begin{array}{l}41 \\
(7)\end{array}$ & $\begin{array}{r}3 \\
(0.1)\end{array}$ & $\begin{array}{l}140 \\
(24)\end{array}$ & $\begin{array}{r}0.37 \\
(0.034)\end{array}$ & $\begin{array}{r}9.7 \\
(2.7)\end{array}$ & $\begin{array}{r}7.6 \\
(5.3)\end{array}$ & $\begin{array}{r}4.7 \\
(0.85)\end{array}$ & $\begin{array}{l}5.7 \\
(3)\end{array}$ & $\begin{array}{r}0.44 \\
(0.17)\end{array}$ & $\begin{array}{r}0.075 \\
(0.033)\end{array}$ & $\begin{array}{r}1.6 \\
(0.68)\end{array}$ & $\begin{array}{r}0.25 \\
(0.053)\end{array}$ & $\begin{array}{r}4.06 \\
(1.25)\end{array}$ \\
\hline Coral fragment & & & & & & & & & & & & & & & & \\
\hline WZ & $\begin{array}{r}120 \\
(105)\end{array}$ & $\begin{array}{r}9.1 \\
(7.6)\end{array}$ & $\begin{array}{r}1.4 \\
(0.36)\end{array}$ & $\begin{array}{l}{ }^{*} 43 \\
(9.2)\end{array}$ & $\begin{array}{r}12 \\
(9.4)\end{array}$ & $\begin{array}{l}1300 \\
(603)\end{array}$ & $\begin{array}{r}2.5 \\
(0.98)\end{array}$ & $\begin{array}{r}15 \\
(8.02)\end{array}$ & $\begin{array}{r}2.6 \\
(0.43)\end{array}$ & $\begin{array}{r}* 3 \\
(0.17)\end{array}$ & $\begin{array}{r}* 2.4 \\
(0.19)\end{array}$ & $\begin{array}{r}0.055 \\
(0.017)\end{array}$ & $\begin{array}{r}0.042 \\
(0.031)\end{array}$ & $\begin{array}{r}0.69 \\
(0.091)\end{array}$ & $\begin{array}{r}2.3 \\
(0.15)\end{array}$ & $\begin{array}{r}0.92 \\
(0.14)\end{array}$ \\
\hline$A Z$ & $\begin{array}{r}95 \\
(20)\end{array}$ & $\begin{array}{r}4.2 \\
(1.03)\end{array}$ & $\begin{array}{r}0.71 \\
(0.16)\end{array}$ & $\begin{array}{r}26 \\
(2.9)\end{array}$ & $\begin{array}{r}8.9 \\
(3.1)\end{array}$ & $\begin{array}{l}1360 \\
(180)\end{array}$ & $\begin{array}{r}2.1 \\
(0.29)\end{array}$ & $\begin{array}{l}17 \\
(4)\end{array}$ & $\begin{array}{r}* 3.3 \\
(0.37)\end{array}$ & $\begin{array}{r}2.8 \\
(0.32)\end{array}$ & $\begin{array}{r}1.1 \\
(0.47)\end{array}$ & $\begin{array}{l}{ }^{*} 0.4 \\
(0.1)\end{array}$ & $\begin{array}{r}0.029 \\
(0.0057)\end{array}$ & $\begin{array}{r}* 0.84 \\
(0.3)\end{array}$ & $\begin{array}{r}* 0.47 \\
(0.023)\end{array}$ & $\begin{array}{r}0.81 \\
(0.15)\end{array}$ \\
\hline CR & $\begin{array}{r}325 \\
(122)\end{array}$ & $\begin{array}{r}18 \\
(6.7)\end{array}$ & $\begin{array}{r}0.79 \\
(0.48)\end{array}$ & $\begin{array}{l}* 24 \\
(8.2)\end{array}$ & $\begin{array}{r}15 \\
(11)\end{array}$ & $\begin{array}{l}1960 \\
(717)\end{array}$ & $\begin{array}{r}2.6 \\
(1.1)\end{array}$ & $\begin{array}{r}24 \\
(11)\end{array}$ & $\begin{array}{r}* 0.22 \\
(0.015)\end{array}$ & $\begin{array}{r}* 0.15 \\
(0.072)\end{array}$ & $\begin{array}{l}* 0.034 \\
(0.072)\end{array}$ & $\begin{array}{r}* 0.0025 \\
(0.00035)\end{array}$ & $\begin{array}{r}0.017 \\
(0.0021)\end{array}$ & $\begin{array}{l}* 0.0083 \\
(0.0039)\end{array}$ & $\begin{array}{r}* 2.7 \\
(0.039)\end{array}$ & $\begin{array}{r}0.012 \\
(0.0016)\end{array}$ \\
\hline KW & 0.0156 & 0.0466 & 0.2299 & 0.0253 & 0.6676 & 0.2971 & 0.7685 & 0.6529 & 0.0005 & 0.0027 & 0.0003 & 0.0003 & 0.0819 & 0.0027 & 0.0102 & 0.0021 \\
\hline
\end{tabular}

$\mathrm{AZ}=$ algal zone. $\mathrm{WZ}=$ wreck zone. $\mathrm{CR}=$ coral reference zone

$\mathrm{KW}=\mathrm{p}$-value of the Kruskal-Wallis test for the three coral medians. Coral means sharing * differ significantly $(p<0.05)$. 
The three convex hulls in the NMS graph (Figure 5) represent the relativised metal compositional pattern of corals sampled from the algal zone, wreck zone, and coral reference zone. A final stress of 3.59 was achieved after 40 iterations, needing only two axes to ordinate the sample points - axis one represents more than $80 \%$ of the variance. Clarke's rule of thumb interprets ordinations with a stress of less than 5 as excellent with no prospect of misinterpretation (McCune \& Grace, 2002). None of the convex hulls overlapped, indicating that the metallic composition of the corals in each of the zones was different. However, the metallic 'fingerprints' of the corals from the algal zone and wreck zone were far more similar, and both clearly distinct from the corals from the coral reference zone. The convex hulls from the affected zones were associated with higher relative proportions of metals such as $\mathrm{Cu}, \mathrm{As}, \mathrm{Cd}$, and $\mathrm{Pb}$, while the coral from the coral reference zone had higher relative proportions of $\mathrm{Au}, \mathrm{B}, \mathrm{Al}$, and Ti. The concentrations of all metals shown in Figure 5 can be found in Supplementary Table 1

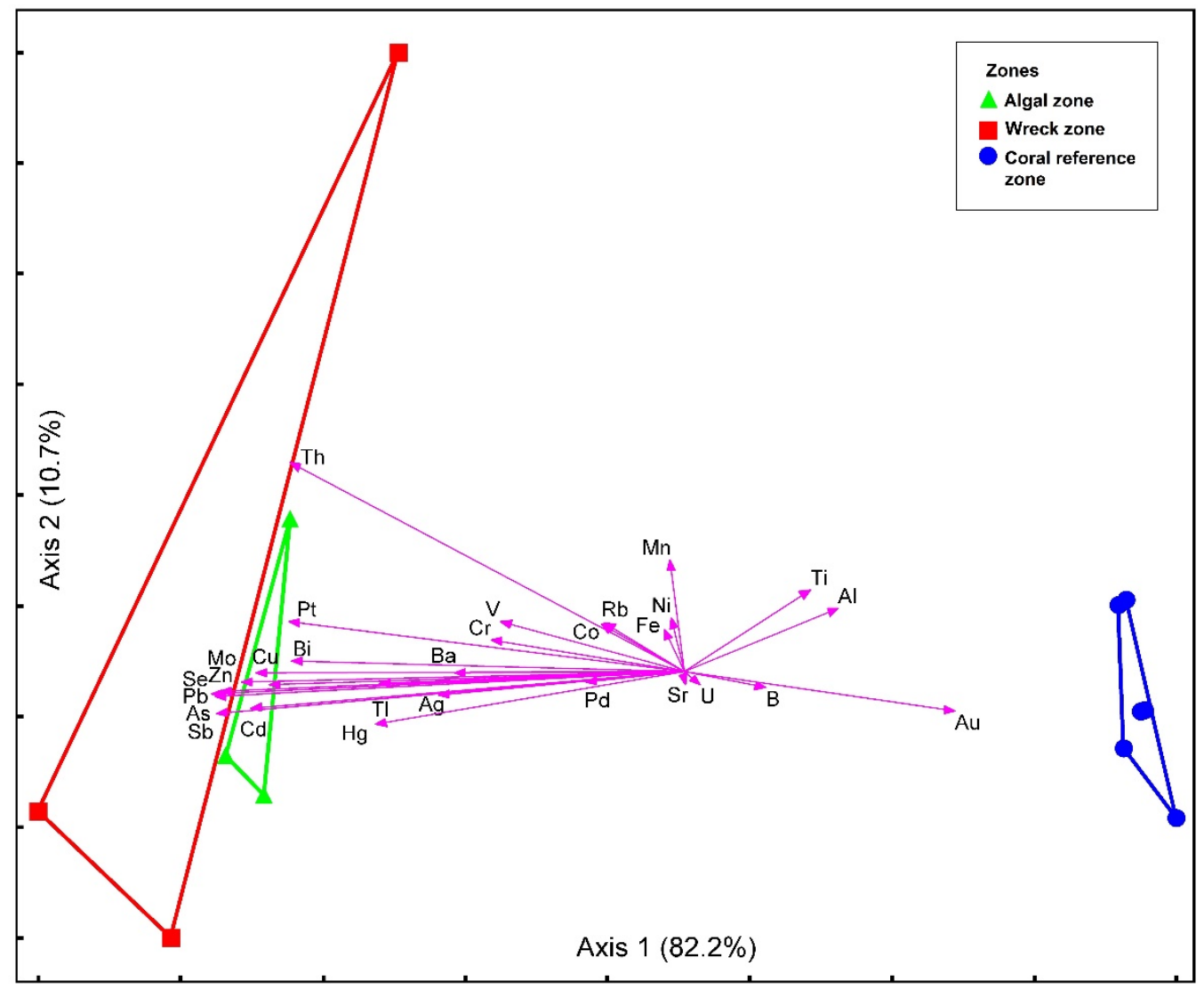

Figure 5. Non-metric, multidimensionally scaled ordination of the relativized metal compositional patterns ('fingerprints') of corals collected from the wreck zone (squares), algal zone (triangles), and the healthy coral reference zone (circles). 


\subsection{Fish and sea cucumber community compositions}

The results of the fish and sea cucumber surveys are listed in Table 2, showing the high density of fish associated with the wreck zone, highest species richness associated with the fish reference zone, and the highest density of sea cucumbers with the algal zone. (Table 2). The algal zone had the lowest species richness and species diversity (Shannon and Simpson indices), and the fish reference zone the highest.

Table 2. Fish and sea cucumber species richness and density. The Shannon and Simpson indices were calculated from the fish reference zone, algal zone, and the wreck zones

\begin{tabular}{lccccc}
\hline Zone & Species richness & Fish $/ \mathbf{~ m}^{\mathbf{2}}$ & Sea cucumbers $/ \mathbf{m}^{\mathbf{2}}$ & Shannon & Simpson \\
\hline $\mathrm{AZ}$ & 5 & 0.82 & 1.5 & 0.72 & 1.6 \\
$\mathrm{WZ}$ & 19 & 4.9 & 0.025 & 1.91 & 3.8 \\
$\mathrm{FR}$ & 25 & 1.9 & 0.095 & 2.19 & 4.8 \\
\hline AZ= algal zone. WZ= wreck zone. FR= fish reference zone
\end{tabular}

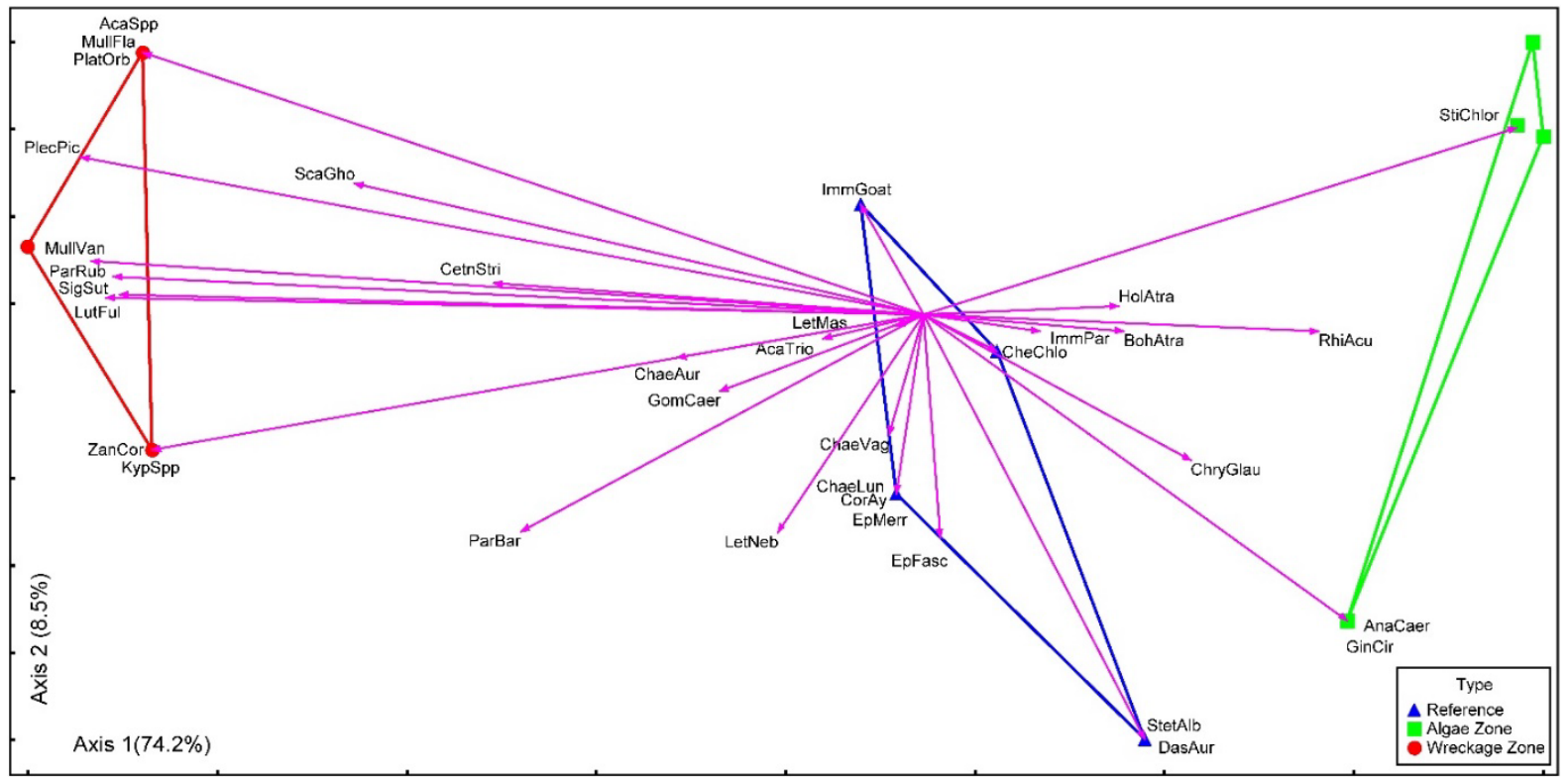

Figure 6. Non-metric, multidimensionally scaled, ordination of relativized fish and sea cucumber composition of the wreck zone, algal zone, and fish reference zone. The vectors represent fish and sea cucumber species. The key to scientific and common names of the organisms are provided in Table 3. 
Table 3. The species name and common names of the fish and sea cucumbers in Figure 6.

\begin{tabular}{|c|c|c|}
\hline NMS abbreviation & Species name & Common name \\
\hline AcaSpp & Acanturus spp. & Surgeon fish \\
\hline AcaTrio & Acanthurus triostegus & Convict surgeonfish \\
\hline AnaCaer & Anampses caeruleopunctatus & Bluespotted wrasse \\
\hline ChaeAur & Chaetodon Auriga & Threadfin butterflyfish \\
\hline ChaeLun & Chaetodon Iunula & Raccoon butterflyfish \\
\hline ChaeVag & Chaetodon vagabundus & Vagabond butterflyfish \\
\hline CheChlo & Cheilinus chlorourus & Floral wrasse \\
\hline ChryGlau & Chrysiptera glauca & Grey demoiselle \\
\hline CorAy & Coris aygula & Clown coris \\
\hline CtenStri & Ctenochaetus striatus & Striated surgeonfish \\
\hline DasAur & Dascyllus auruanus & Whitetail dascyllus \\
\hline EpFasc & Epinephelus fasciatus & Blacktip grouper \\
\hline EpMerr & Epinephelus merra & Honeycomb grouper \\
\hline GinCir & Ginglymostoma cirratum & Nurse shark \\
\hline GomCaer & Gomphosus caeruleus & Green birdmouth wrasse \\
\hline ImmGoat & Mulloidichthys spp. & Small immature goatfish \\
\hline ImmPar & Scarus spp. & Small immature parrotfish \\
\hline KypSpp & Kyphosus spp & Grey chub \\
\hline LetMas & Lethrinus mahsena & Sky emperor \\
\hline LetNeb & Lethrinus nebulosus & Spangled emperor \\
\hline LutFul & Lutjanus fulviflamma & Dory snapper \\
\hline MullFla & Mulloidichthys flavolineatus & Yellowstripe goatfish \\
\hline MullVan & Mulloidichthys vanicolensis & Yellowfin goatfish \\
\hline ParBar & Parupeneus barberinus & Dash-and-dot-goatfish \\
\hline ParRub & Parupeneus rubescens & Rosy goatfish \\
\hline PlatOrb & Platax orbicularis & Orbicular batfish \\
\hline PlecPic & plectorhinchus picus & Painted sweetlips \\
\hline RhiAcu & Rhinecanthus aculeatus & White-banded triggerfish \\
\hline ScaGho & Scarus ghobban & Blue-barred parrot \\
\hline SigSut & Siganus sutor & Shoemaker spinefoot \\
\hline StetAlb & Stethojulis albovittata & Bluelined wrasse \\
\hline ZanCor & Zanclus cornutus & Moorish idol \\
\hline BohAtra & Bohadschia atra & Sea cucumber \\
\hline HolAtra & Holothuria atra & Lollyfish sea cucumber \\
\hline StiChlor & Stichopus chloronotus & Greenfish sea cucumber \\
\hline
\end{tabular}

The fish and sea cucumber compositions of the three zones were very different from one another (Figure 6 ) indicated by the non-overlap of the convex hulls. Two dimensions were needed, reached after 55 iterations, a stress $<0.00001$, with a final stress of 2.87 ; again a very good representation. Most of the fish species were associated with the wreck zone but were also present in the fish reference zone. Whilst only a few fish species 
ordinated towards the algal zone, both sea cumber species (Holothuria atra and Stichopus chloronotus) ordinated towards the algal zone convex hull, representing the high occurrence of sea cucumbers there. Although they were not found on the other transects and at the wreck sites, 11 hawksbill sea turtles (Eretmochelys imbricata) were seen feeding on the algae in the algal zone. Two nurse sharks (Ginglymostoma cirratum) were also seen in the algal zone. The fish that was most often seen in the algal zone was the herbivorous Chrysiptera glauca (Branch et al., 2016). White-banded triggerfish (Rhinecanthus aculeatus) were the second most abundant fish in the algal zone.

\section{Discussion}

\subsection{Metals in corals}

Pollution originating from fossil fuel spillage (Vouk \& Priver, 1983; Prego \& CobeloGarcía, 2004, Landquist et al., 2013), corrosion of electronic waste (Hahladakis et al., 2013), and antifouling paint (IMO, 2002) are usually associated with shipwrecks. Lead, Hg, Se, As, $\mathrm{Cu}, \mathrm{Zn}, \mathrm{Cd}$ are associated with fossil fuels (Vouk \& Priver, 1983; Prego \& Cobelo-García, 2004). All these elements were present in higher concentrations in coral from the affected area (wreck zone and algal zone combined). Chronic exposure to oil can cause reproductive failure, cellular degradation, and atrophy in Stylophora corals (Peters et al., 1981). Elevated concentrations of $\mathrm{Zn}$ and $\mathrm{Cd}$ are metals known to be associated with so-called green tide algae blooms (Ge et al., 2017). Corals from the affected areas contained higher concentrations of these metals than corals from the coral reference zone. It is evident that the presence of the wreck amplified these metal concentrations beyond the background concentrations of the natural reef.

In addition, it was found that the paint from the wreck contained high concentrations of Cu (103 $000 \mathrm{mg} / \mathrm{kg}$ ), Fe (702 $000 \mathrm{mg} / \mathrm{kg}$ ), Al (59 $000 \mathrm{mg} / \mathrm{kg}$ ) Ti (18 $000 \mathrm{mg} / \mathrm{kg})$, and Pb (1 $800 \mathrm{mg} / \mathrm{kg}$ ). The standard deviations are high, probably reflecting different paint histories over different parts of the ship. Since restrictions were placed on maritime companies by the International Maritime Organisation (IMO) to eliminate the use of tributyltin (TBT) as an antifoulant, copper-based replacements have become increasingly popular (IMO, 2002). High concentrations of $\mathrm{Cu}$ and $\mathrm{Zn}$ originating from antifoulant paint had been found in sediment around other shipwrecks in previous studies (Jones, 2007). The wreck in SBR had been painted in a shipyard in Mauritius before its last voyage (Merven, J. Pers Obs. 2014). This fresh coat of paint may be a reason for the high $\mathrm{Cu}$ concentration in the paint of the wrecked ship.

Lead was also found in paint samples from the wreck, at $1800 \mathrm{mg} / \mathrm{kg} \mathrm{dm}$. This $\mathrm{Pb}$ most likely caused lead concentrations two orders of magnitude higher in algal zone and the 
wreck zone coral than in coral from the coral reference zone (Table 2). Despite the strong movement of banning lead from paints, it is still found in hull paints. Although lead in paint is rather insoluble and therefore will leach slower than Cu or Zn (Turner, 2014), abrasion of the hulls, as was seen through the scouring of the coral reef lagoon, will release paint chips.

Although most metals were found in significantly higher concentrations in coral from the wreck-affected areas, some metals did not follow this same pattern. Iron, $\mathrm{Al}, \mathrm{Ti}, \mathrm{Co}, \mathrm{Ni}$, and $U$ concentrations were lower in the affected area than in the coral reference zone. This was unexpected, because the coral reference zone was situated on the other side of the atoll, and these corals were isolated from the effects of the wreck in question.

\subsection{Algal bloom and black reef}

Coral thrives in nutrient poor waters (Sheppard et al., 2009). Shipwrecks have the potential to create a nutrient influx that promotes algal growth that out competes coral growth (Sheppard et al., 2009). The nutrients promoting algal growth might have been released when the cargo hold and the ballast water tank of the fishing vessel broke after being dragged over the reef crest by currents and waves (Littler et al., 2006; Humanes et al., 2016). The ballast water that ships require for stabilization are known vectors of Ulva spp. spores (Flagella et al., 2007; Aguirre-Macedo et al., 2008). We speculate that the initial Ulva spp. spores that caused the bloom were transported by ballast water.

The wreck in question was a tuna longliner. It stands to reason that the cargo hold would contain bait and the tuna that were caught prior to the wreckage event. These fish would have thawed and decayed. When the cargo hold containing the fish tissue broke open, the contents would have been released to the reef in a nutrient influx from the decomposed fish. We do not know whether this release occurred all of a sudden when the hull was breached, or gradually over time through slow leakage. Both scenarios would favour bottom-up eutrophication (Littler \& Littler, 1984) which could play a large role in an algae-coral phase shift, favouring algal growth over coral growth.

Normally, algal growth on live and healthy coral would be visibly absent due to intense grazing by herbivores and active cleaning of the surface by the coral itself (Nugues et al., 2004). However, since the corals in the algal zone were compromised by inter alia elevated metal concentrations (Table 1) and possibly nutrient and fuel oil release, the natural cleaning mechanisms of the coral were presumably compromised. Herbivory by small fish was insufficient to prevent the algal growth.

Black reefs are generally thought to be induced by an iron influx from shipwreck debris on the reef causing a bloom in cyanobacteria and turf algae (Schroeder et al., 2008; Kelly et al., 2012; Mangubhai \& Obura, 2019). Three other instances of black reefs was found in the literature; Rose Island, Samoa (Schroeder et al., 2008), Line Island (Kelly et al., 
2012), and Phoenix Island (Mangubhai \& Obura, 2019) in the Central Pacific. Kelly et al. (2012) reported a change from pristine to a black reef condition over three years with no recovery noted after five years. On Rose Island, the effects of the wreck was visible thirteen years after the initial wreck (Schroeder et al., 2008). We do not have data or observations on when the reef at St. Brandon's turned black. Since the wreck travelled over six kilometres over the lagoon since wrecking two years before while breaking up into three pieces suggests a much quicker blackening effect. Since our visit in 2014 , we have no reports whether the blackened condition persists.

\subsection{Fish and sea cucumber community structure}

Figure 6 shows that while the wreck zone had the highest fish abundance, the fish reference zone contained the highest species diversity. The fish that occurred in the wreck zone were predominantly large and at a higher trophic level (Branch et al., 2016).

Even though some tourism does occur on the atoll, small-scale commercial fishing is the main economic activity practiced in the area. Frozen and salted fish are transferred from the outer atoll system to the Mauritian main island. Fishers mainly target spangled emperors (Lethrinus nebulosus) and sky emperors (Lethrinus mahsena) - both predatory fish that were found in abundance around the wreck.

Coralliverous fish, such as species of the genus Chaetedon (butterfly fish), were mostly found in the fish reference zone. This makes sense as the coral of the fish reference zone was, on face value, the healthiest. The coral in the fish reference zone did not exhibit the blackened coloration of the coral from the wreck zone and were unaffected by the algal bloom of the algal zone.

Macroalgae blooms can change biochemical cycles and the community structures, and decrease biodiversity of an area (Choi et al., 2010). This was seen in SBR, where the algal zone had the lowest species richness and species diversity (Table 2). The majority of fish found between the algae strands were either herbivorous or predators of sea cucumbers. Most of the fish found in the algal zone were also large individuals. Several hawksbill sea turtles were found in the algal zone, but not in the other areas, suggesting that they feed on the algae and associated metals (Table 1).

The organisms that were most often encountered in the algal zone were sea cucumbers. We surmise that the high numbers of sea cucumbers were attracted to the affected area due to the detritus biomass resulting from the broken reef and algal bloom upon which they could feed. Elsewhere in the SBR lagoon, the observation of high numbers of sea cucumbers in the track of the wreck being pushed by currents through the coral of the lagoon supports this deduction. 
Owning to their effective defence mechanism, very few fish actively prey on sea cucumbers. However, predation by trigger fish and emperor fish have been recorded (Dance et al., 2003). Even though no predation was observed during our study, it is likely that the trigger fish and emperor fish of the algal zone might hunt sea cucumbers there (Branch et al., 2016).

\subsection{Potential for trophic transfer}

The most abundant organism we counted in the algal zone was the sea cucumber (Table 2). Although collection permits obtained for this research did not allow collection of sea cucumbers, the effects of metals on the organism can be inferred through the literature. $\mathrm{Li}$ et al. (2016) found that elevated $\mathrm{Cu}, \mathrm{Cd}$, and $\mathrm{Zn}$ concentrations contributed to negative effects on the sea cucumbers' respiration, muscle tissue, and intestinal tract. Sea cucumbers are seldom the target prey of fish, but several fish will prey on them if other prey is scarce. Emperor fish and trigger fish are known to prey opportunistically on sea cucumbers (Branch et al., 2016; Dance et al., 2003). Approximately $80 \%$ of SBR's fish export consists of emperor fish, Lethrinus mahsena (Boistol et al., 2011). If the sea cucumbers contain these and other metals in their tissue, trophic transfer will be expected to occur through biomagnification if the fish prey on the echinoderms (Newman, 2010). People can be exposed to these metals when they eat the fish containing metals (Pheiffer et al., 2014). Fish such as butterfly fish and parrot fish that prey on coral and coral associated algae are also at risk of being affected by elevated levels of metals through biomagnification (Newman, 2010).

Eleven hawksbill sea turtles were found feeding on the algal bloom. Hawksbill sea turtles are considered Critically Endangered by the International Union for Conservation of Nature (IUCN) Red List (Mortimer \& Donnelly, 2008). They are exposed to metals in algae through ingestion. Metals such as $\mathrm{Cu}, \mathrm{As}$, and $\mathrm{Pb}$ are elevated in algae from the bloom area and are known to affect sea turtle physiology adversely (Du Preez et al., 2018).

\section{Assessment and recommendations}

The shallow shipwreck we surveyed caused an ecological shift in species distribution and benthic cover. Around the wreck zone and algal zone, the corals were visibly negatively affected or dead. The coral from the affected area and coral reference zone all contained quantifiable concentrations of several metals detrimental to the environment.

Due to the remoteness of SBR, no follow-up study was possible to determine whether the wreck- and algal zones had completely recovered. The algae had largely dissipated after a large storm had swept through the atoll in 2015 (Merven, J. Pers. Com. 2015). However, the toxicological effects may remain in the environment for a long time as the metals would persist due to the presence and ongoing breakdown of the wreck and 
remain longer in coral and coral rubble. Precht et al., (2001) stated that the damage caused by shipwrecks could take more than ten years to mitigate.

Because of the potential bioaccumulation of pollutants by emperor fish and sea turtles, and the species' close association with shipwreck structures, consideration should be given to removing shipwrecks from the atoll as soon as possible without causing more damage. Furthermore, fish and other foods obtained near shipwrecks may contain elevated metal concentrations, detrimental to human health, that need to be monitored.

Studying the effects of major disturbances such as shipwrecks on reefs are difficult as such disturbances itself are not predictable, desirable, replicable, or easily restorable. Before-and-after-control studies are therefore only possible in previously surveyed areas. However, our findings show that the occurrences of shipwrecks on coral reefs needs to be included as a potential impact factor on coral reef ecosystems. The effects of a shipwreck seem not only to be limited to the impact point itself, or even the subsequent location of any wreck, but down-current effects need also be considered.

\section{Acknowledgements}

We thank the Raphaël Fishing Company, in particular the crew of Patrol One. Permission to visit the atoll was granted by the Outer Islands Development Corporation, Republic of Mauritius. We also thank the Persistent Organic Pollutant and Toxicant (POPT) editorial collective of the NWU and Elmarie van der Schyff for many improvements to the manuscript. Funding was provided by the South African Regional Cooperation Fund for Scientific Research and Technological Development (UID 65290) administered by the South African National Research Foundation (NRF). The Chemical Industries Education \& Training Authority (CHIETA) is thanked for their support. Opinions expressed and conclusions arrived at are those of the authors and are not necessarily to be attributed to any of the funders. This article forms part of a PhD thesis (Veronica van der Schyff).

Authors declare no competing interests.

\section{References}

Aguirre-Macedo, M.L., Vidal-Martinez, V.M., Herrera-Silveira, J.A., Valdés-Lozano, D.S., Herrera-Rodríguez, M. \& Olvera-Novoa, A. 2008. Ballast water as a vector of coral pathogens in the Gulf of Mexico: The case of the Cayo Arcas coral reef. Marine Pollution Bulletin: 56: 1570-1577

Allen, A.S., Seymour, A.C. \& Rittschof, D. 2017. Chemoreception drives plastic consumption in a hard coral. Marine Pollution Bulletin, 124: 198-205.

Barneah, O., Ben-Dov, E., Kramarsky-Winter, E. \& Kushmaro, A. 2007. Characterization of black band disease in Red Sea stony corals. Environmental microbiology, 9: 1995-2006. 
Barrett, M.J. 2011. Potentially polluting shipwrecks: Spatial tools and analysis of WWII shipwrecks. Masters project submitted in partial fulfilment of the Master of Environmental Management degree. Nicholas School of the Environment, Duke University.

Baumann, J.H., Ries, J.B., Rippe, J.P., Courtney, T.A., Aichelman, H.E., Westfield, I. \& Castillo, K.D. 2019. Nearshore coral growth declining on the Mesoamerican Barrier Reef System. Global change biology.

Boistol, L., Harper, S., Booth, S. \& Zeller, D. 2011. Reconstruction of marine fisheries catches for Mauritius and its outer islands, 1950-2008. Fisheries Centre Research Reports, 19:39-61.

Bouwman, H., Evans, S.W., Cole, N., Yive, N.S.C.K. \& Kylin, H. 2016. The flip-or-flop boutique: Marine debris on the shores of St Brandon's rock, an isolated tropical atoll in the Indian Ocean. Marine Environmental Research, 144: 58-64.

Branch, G., Griffiths, C., Branch, M. \& Beckley, L. 2016. Two Oceans, A guide to the marine life of southern Africa. $4^{\text {th }}$ ed. Struik Nature. Cape Town. 464p.

Carpenter, K.E., Abrar, M., Aeby, G., Aronson, R.B., Banks, S., Bruckner, A., Chiriboga, A., Cortes, J., Delbeek, J.C., DeVantier, L., Edgar, G.J., Edwards, A.J., Fenner, D., Guzman, H.M., Hoeksema, B.W. Hodgson, G., Johan, O., Licuanan, W.Y., Livingstone, S.R., Lovell, E.R., Moore, J.A. Obura, D.O. Ochavillo, D., Polidoro, B.A., Precht, W.F., Quibilan, M.C., Reboton, C., Richards, Z.T., Rogers, A.D., Sanciangco, J., Sheppard, A., Sheppard, C., Smith, J., Stuart, S., Turak, E., Veron, J.E.N., Wallace, C., Weil, E. \& Wood, E. 2008. One-third of reef-building corals face elevated extinction risk from climate change and local impacts. Science, 321: 560-563.

Choi, T.S., Kang, E.J., Kim, J.H. \& Kim, K.Y. 2010. Effect of salinity on growth and nutrient uptake of Ulva pertusa (Chlorophyta) from an eelgrass bed. Algae: 25: 17-26.

Consoli, P., Martino, A., Romeo, T., Sinopoli, M., Perzia, P., Canese, S., Vivona, P. \& Andaloro, F. 2015. The effect of shipwrecks on associated fish assemblages in the central Mediterranean Sea. Journal of the Marine Biological Association of the United Kingdom, 95: 17-24.

Dance, S. K., Lane, I. \& Bell, J. D. 2003. Variation in short-term survival of cultured sandfish (Holothuria scabra) released in mangrove-seagrass and coral reef flat habitats in Solomon Islands. Aquaculture, 220: 495-505.

Du Preez, M., Nel, R. \& Bouwman. H. 2018. First report of metallic elements in loggerhead and leatherback turtle eggs from the Indian Ocean. Chemosphere, 197: 716-728.

Evans, S.W., Cole, N., Kylin, H., Choong Kwet Yive, N.S., Tatayah, V., Merven, J. \& Bouwman, H. 2016. Protection of marine birds and turtles at St Brandon's Rock, Indian Ocean, requires conservation of the entire atoll. African Journal of Marine Science, 38: 317-327.

Flagella, M.M., Verlaqu, M., Soria, A. \& Buia, M.C. 2007. Macroalgal survival in ballast water tanks. Marine Pollution Bulletin: 54: 1395-1401

Gardner, T.A. Côté, I.M., Gill, J.A., Grant, A. \& Watkinson, A.R. 2003. Long-Term RegionWide Declines in Caribbean Corals. Science, 301: 958-960.

Ge, C., Yu, X., Kan, M. \& Qu, C., 2017. Adaption of Ulva pertusa to multiple-contamination of heavy metals and nutrients: Biological mechanism of outbreak of Ulva sp. green tide. Marine Pollution Bulletin, 125: 250-253.

Hahladakis, J.N., Stylianos, M. \& Gidarakos, E. 2013. Assessment of released heavy metals from electrical and electronic equipment (EEE) existing in shipwrecks through laboratoryscale simulation reactor. Journal of Hazardous Materials, 250-251: 256- 264. 
Hancock, P. 2018. Shipwreck Logs: A log of shipwrecks \& maritime accidents around the world. https://shipwrecklog.com/log/tag/cargados-carajos-shoals/. Date of access: 8 September 2018.

Hughes, T.P., Kerry, J.T., Baird, A.H., Connolly, S.R., Dietzel, A., Eakin, C.M., Heron, S.F., Hoey, A.S., Hoogenboom, M.O., Liu, G. \& McWilliam, M.J. 2018. Global warming transforms coral reef assemblages. Nature, 556(7702), p.492.

Humanes, A., Noonan, S.H., Willis, B.L., Fabricius, K.E. \& Negri, A.E. 2016. Cumulative Effects of Nutrient Enrichment and Elevated Temperature Compromise the Early Life History Stages of the Coral Acropora tenuis. PLoSOne. 11: e0161616

International Maritime Organisation (IMO). 2002. Anti-fouling systems. Focus on IMO. www.imo.org. Date accessed: 30/10/2018.

Jompa, J. \& McCook, L.J. 2003. Coral-algal competition: macroalgae with different properties have different effects on corals. Marine Ecology Progress Series, 258: 87-95.

Jones, R.J. 2007. Chemical contamination of a coral reef by the grounding of a cruise ship in Bermuda. Marine Pollution Bulletin, 54: 905-911.

Kelly, L.W., Barott, K.L., Dinsdale, E., Friedlander, A.M., Nosrat, B., Obura, D., Sala, E., Sandin, S.A., Smith, J.E., Vermeij, M.J.A., Williams, G.J., Willner, D. \& Rohwer, F. 2012. Black reefs: iron-induced phase shifts on coral reefs. The International Society for Microbial Ecology Journal, 6: 638-649.

Landquist, H., Hassellöv, I-M., Rosén, L., Lindgren, J.F. \& Dahllöf, I. 2013. Evaluating the needs of risk assessment methods of potentially polluting shipwrecks. Journal of Environmental Management, 119: 85-92.

Li, L., Tian, X., Yu, X. \& Dong, S. 2016. Effects of acute and chronic heavy metal (Cu, Cd, and $\mathrm{Zn}$ ) exposure on sea cucumbers (Apostichopus japonicus). BioMed Research International, 2016: 13p.

Littler, M.M. \& Littler, D.S. 1984. A relative-dominance model for blotlc sciences. Proceedings of the Joint Meeting of the Atlantic Reef Coggnitte Society of Reef Studies, Miami, Florida.

Littler, M.M., Littler, D.S. \& Brooks, B.L. 2006. Harmful algae on tropical coral reefs: Bottomup eutrophication and top-down herbivory. Harmful algae, 5: 565-585.

Mangubhai, S. \& Obura, D.O. 2019. Silent killer: black reefs in the Phoenix Islands Protected Area. Pacific Conservation Biology, 25: 213-214.

McCook, L.J., Jompa, J. \& Diaz-Pulido, G. 2001. Competition between corals and algae on coral reefs: A review of evidence and mechanisms. Coral Reefs, 19: 400-417.

McCune, B. \& Grace, J.B. 2002. Analysis of ecological communities. MjM Software Design, Gleneden Beach, Oregon.

Millero, F., Woosley, R., Di Trolio, B. \& Waters, J. 2009. Effect of ocean acidification on the speciation of metals in seawater. Oceanography, 22: 72-85.

Mortimer, J.A. \& Donnelly, M. 2008. IUCN SSC Marine Turtle Specialist Group. Eretmochelys imbricata. The IUCN Red List of Threatened Species 2008. http://dx.doi.org/10.2305/IUCN.UK.2008.RLTS.T8005A12881238.en. Date of access: 14 April 2019.

Newman, M.C. 2010. Fundamentals of Ecotoxicology. $3^{\text {rd }}$ ed. CRC Press: Boca Raton. $541 \mathrm{p}$.

Nugues, M.M., Delvoye, L. \& Bak, R.P.M. 2004. Coral defence against macroalgae: differential effects of mesenterial filaments on the green alga Halimeda opuntia. Marine Ecology Progress Series, 278: 103-114. 
Perkol-Finkel, S., Shasar, N. \& Benayahu, Y. 2006. Can artificial reefs mimic natural reef communities? The roles of structural features and age. Marine Environmental Research. 61: 121-135.

Peters, E.C., Meyers, P.A., Yevich, P.P. \& Blake, N.J. 1981. Bioaccumulation and Histopathological Effects of Oil on a Stony Coral. Marine Pollution Bulletin, 12: 333-339.

Pheiffer, W., Pieters, R., van Dyk, J. C., \& Smit, N. J. 2014. Metal contamination of sediments and fish from the Vaal River, South Africa. African Journal of Aquatic Science, 39: 117-121.

Porter, S.N. \& Schleyer, M.H., 2017. Long-term dynamics of a high-latitude coral reef community at Sodwana Bay, South Africa. Coral Reefs, 36: 369-382.

Precht, W.F., Aronson, R.B. \& Swanson, D.W. 2001. Improving scientific decision-making in the restoration of ship-grounding sites on coral reefs. Bulletin of Marine Science, 69: 1001-1012.

Prego, R. \& Cobelo-García, A. 2004. Cadmium, copper and lead contamination of the seawater column on the Prestige shipwreck (NE Atlantic Ocean). Analytica Chimica Acta, 524: 23-26.

Quod, J.P. 1999. Consequences of the 1998 coral bleaching event for the islands of the western Indian Ocean. CloeCoop, Cellule Locale pour l'Environnement.

Raymundo, L.J., Licuanan, W.L. \& Kerr, A.M. 2018. Adding insult to injury: Ship groundings are associated with coral disease in a pristine reef. PLoS one, 13(9), p.e0202939.

Schott, F.A. \& McCreary Jr., J.P. 2001. The monsoon circulation of the Indian Ocean. Progress in Oceanography, 51:1-123.

Schroeder, R.E., Green, A.L., DeMartini, E.E. \& Kenyon, J.C. 2008. Long-term effects of a ship-grounding on coral reef fish assemblages at Rose Atoll, American Samoa. Bulletin of Marine Science, 82: 345-364.

Sheppard, C.R., Davy, S.K. \& Pilling, G.M. 2009. The biology of coral reefs. Oxford University Press: Oxford. 339p.

Turner, A. 2014. Mobilisation and bioaccessibility of lead in paint from abandoned boats. Marine Pollution Bulletin, 89: 35-39.

Vouk, V.B. \& Piver, W.T. 1983. Metallic elements in fossil fuel combustion products: amounts and form of emissions and evaluation of carcinogenicity and mutagenicity. Environmental Health Perspective, 47: 201-225.

Yuping, Z., Liju, T., Qiuting, P., Feng, L. \& Jiangtao, W. 2015. Influence of nutrients pollution on the growth and organic matter output of Ulva prolifera in the southern Yellow Sea, China. Marine Pollution Bulletin, 95: 107-114.

Yusuf, S. 2014. Investigation of coral reef degradation due to 'ship grounding'. Proceedings of the International Conference on Marine Science and Fisheries. Makassar, 10-11 September 2014. Identitas Publications. pp: 11-19.

Zertuche-González, J.A., Camacho-Ibar, V.F., Pacheco-Ruíz, I., Cabello-Pasini, A., GalindoBect, L.A., Guzmán-Calderón, J.M., Macias-Carranza, V. \& Espinoza-Avalos, J. 2009. The role of Ulva spp. as a temporary nutrient sink in a coastal lagoon with oyster cultivation and upwelling influence. Journal of Applied Phycology, 21: 729. 